\title{
Interrogating Orthodox Voices: Gender, Ethnicity and Educational Leadership
}

Research in educational leadership and management, while comprehensive in its scope and direction, has considerable imbalances that have contributed to what Blackmore (1999) has termed the monoculture of the powerful. The focus on the apparent intractability of leadership as a male domain and ways in which women have negotiated the gendered nature of their professional lives has provided opportunities for debate and the emergence of (oppositional) discourses that account for women's ways of knowing and leading. Yet, as this article argues, these discourses of privilege and opportunity have not accounted for trajectories of ethnicity and diversity. The critique of western ethnocentric notions of leadership presented in this article is informed by debates on issues such as gender and educational leadership that have produced meta-narratives that explore and explain women and men's ways of leading. One of the troubling aspects of western leadership theories is the claim that the functions and features of leadership can be transported and legitimated across homogenous educational systems. Despite changes that have been made in definitions and descriptions of educational leadership to provide a focus on gender, there is the implicit assumption that while educational leadership might be practised 
differently according to gender, these discourses essentially remain both raced and classed. Thus, the construct of educational leadership needs to be more broadly theorised in order for cross-cultural discourses to emerge.

\section{Introduction}

Recent theoretical and empirical studies on women and educational leadership that have emerged predominantly from the United States (Chase, 1995; Grogan, 1996; Shakeshaft 1987), Britain (Adler, Laney and Packer, 1993; Coleman, 2001; Ozga, 1993), Australia (Blackmore, 1999; Limerick and Lingard, 1995) and New Zealand (Court, 1995, 1998; Strachan, 1999) can be conceptualised in terms of three complementary and overlapping domains; profiles, patterns and practice. The first domain or 'gender script' as Blackmore suggests (2002:56) refers to studies that provide demographic data and explore characteristics, attitudes, opinions and perceptions of selected issues. These data contribute to an understanding of the broader socio-political environment in which women as leaders operate as a numerical minority. The second domain offers explanations of career patterns and issues related to career aspirations, access to leadership opportunities, employment strategies, mentoring, professional barriers, retention and experiences of women leaders. Arguably, the central focus of these studies is the way in which women leaders face occupational and professional challenges and can be termed 'discourses of opportunity'. That is, the achievement of women in acquiring and exercising leadership positions is related to opportunities of access and personal or professional strategies. The final 
domain encompasses a wide range of inquiry that seeks to understand the nature of the various educational, managerial and political roles and draws attention to issues of power, visibility, collaboration, conflict and change management. In subliminal and subtle ways, this literature provides a relief map of women's ways of knowing and leading and furthermore charts ways in which women inevitably exercise leadership in schools. In the process, debates centred on the common theme that 'gender matters in educational leadership' (Blackmore and Kenway, 1993; Hall, 1999; Shakeshaft, 1987) have produced what I term 'discourses of privilege'. That is, women as educational leaders have been theorised about as if they form a collective identity based on their gender and the sharing of common experiences and struggles. In the main, the majority of women who 'succeed' in (white) male-dominated cultures such as schools have achieved a level of status and privilege (Bourdieu, 1987) that is predicated on western traditions and has produced a particular kind of implicit consensus amongst these women about the issues which are thought to be important to organise around. Hence my suggestion that the personal and professional work narratives of women who assume leadership positions contribute to 'discourses of privilege'. And, in numerous ways, our colonial heritage marches on.

Although there remains a focus on women and educational leadership, considerations of circumstances such as ethnicity/social class/location and beliefs that speak to different dimensions of identity have been discounted. Or, at the very least, distinctions between and among women have collapsed in the attempt to provide a meta-narrative that describes and defines women's 
experiences and practices as educational leaders (Essed, 2000). Against a backdrop of the contested and continuing reform of educational administration, discourses that universalise the complex participation of 'women' and 'women's leadership' have produced somewhat troublesome narratives that point to the prevalence of what I consider to be 'discourses of identity'. Categories of 'women' and 'educational leader' have become fixed and the possibility for substantive diversity among and between women does not appear possible. And less recognised is the way in which whiteness becomes a privileging construct that is played out differently across gendered lines. Accordingly, the multiple and complex silences that surround these discourses of privilege, identity and of opportunity are deafening (Fitzgerald, 2003). Essentially while accounts of 'masculinity, rationality and leadership' (Blackmore, 1999:4) and the search for a normative theory of leadership (Duke, 1998) remain gendered, they also remain raced. That is, considerations of race and ethnicity are not explicitly uncovered to examine ways in which these trajectories impact on the exercise of educational leadership.

\section{Gender, Leadership and Ethnicity}

Women from ethnic groups other than white are a minority group in a minority setting. Discussing differences and distinctiveness within the scope of educational leadership is complicated, contested and dangerous terrain. Partially this is because it is a taken-for-granted assumption that 'difference', 'diversity' and 'distinctiveness' immediately refers to identification with a particular ethnic 
group. Constructs of race, ethnicity and gender are, as Cynthia Dillard suggests, 'slippery constructs' (Dillard, 2000:670). And how might these multiplicities of identity contribute to a broader understanding of the exercise of educational leadership? While feminist research might assist with deciphering common gender differences and experiences, discussions surrounding race and ethnicity are ideologically and methodologically more complex. What is inherently problematic is that whiteness as a race, privilege and social construct remains a silence in our theorising (Fine, 1997; Moreton-Robinson, 2000). The politics of gender and ethnicity define women in general and women from ethnic minority groups in particular, as problems in two specific ways. In the first instance, categorical definitions render women as a female problem and secondly, race as a minority problem. As Sue Adler et al., (1993) have pointed out, these categories allow women from dominant (and white) groups to identify themselves as women, not as white women. In this way, whiteness is the taken for granted norm that is deemed to be stable, unified and homogenous. Difference is therefore expressed as a corollary of whiteness and has the potential to create a monoculture of the powerful (Blackmore, 1999) that is expressed in gender and race specific ways as Penny Tripconey (1995) has documented. What is being suggested here is that there is an interconnectedness between 'whiteness' and 'other colours' (Fine, 1997). In terms of research for/about educational leadership, whiteness has remained theoretically and empirically unstudied. Consequently, I would argue, the filter of whiteness has been constructed and positioned as the (privileged and discursive) 'norm'. 
If whiteness is taken as the standpoint for our theorising, then accounts of difference suggest an 'adding-on' to these narratives and that difference to/from the norm of whiteness creates what can be termed 'discourses of deficit'; difference is therefore located as a binary opposite and determined by the dominant group. There is arguably a lexical slip between 'difference' and 'deficient' yet there exists a theoretical displacement. A further difficulty is that the production of a universal explanation of 'gender, leadership and ethnicity' could produce a 'discourse of homogeneity' that constrains women from dominant and minority groups to act and work in particular ways. Thus, what I am advocating is an avoidance of 'discourses of homogeneity'. We cannot unilaterally assume that experiences of women based on their social and ethnic location are the same or similar. It is not my intention to paralyse our theorising by suggesting that discourses of diversity are inherently problematic, complex, contradictory and therefore not able to be reconstituted. What we do need to avoid is subscribing to hegemonic discourses that articulate and advocate normative ways of managing and leading. We must be prepared to interrogate our compliance and the orthodoxies that this has the potential to produce.

In recent years there have been increasing numbers of studies conducted that specifically report on the obstacles and exercise of educational leadership by 'black women in educational management' (Alston, 1999; Blackmore, 1999; McGee Banks, 2000; Shakeshaft, 1987; Slack and Cornelius, 1995). A cursory glance at these texts could suggest that the reporting of findings has been organised in a marginal way and have contributed to what I termed earlier 
'discourses of privilege'. Invariably the initial chapters document the participation and experiences of 'women and educational leadership' and it is not until the latter chapters that the focus turns to the problematic nature of educational leadership and gender, race and ethnicity. One criticism of these studies is that women of colour are labelled as one group thereby negating their distinctiveness based on ethnicity, family, geographical location, language, social and familial relationships, knowledge, spirituality, philosophy and aspiration (MoretonRobinson, 2000:xviii). Women from minority groups face a number of central challenges. On the one hand as women in hierarchies dominated in the main by white men and, on the other hand, as women in a marginal position due to the numerical dominance of white women (Alston, 1999, 2000; Dillard, 2000; Essed, 2000).

A further difficulty is the double bind that Indigenous women in particular face (Blackmore, 1999:199). While Indigenous women represent their communities, they are implicitly expected (by Pakeha/white administrators) to work as change agents to simultaneously challenge existing power structures in their educational organisations (Fitzgerald, 2003). The experience of Maori women educators in Aotearoa/New Zealand would suggest that their visible presence in schools requires them to advocate for Maori pupils (including involvement in discipline and counselling), act on behalf of the school with the local Maori community, organise all the cultural groups and formal performances and have a voice on 'Maori issues'. Yet similar professional expectations and demands are not made or expected of their female Pakeha colleagues to engage 
in 'mammy work' (Collins, 1998:49) as well as the politics of identity and community (Essed, 2000).

It is timely to consider interrogating and re-defining educational leadership and management as a knowledge domain to ensure that gender and ethnicity, including whiteness, are theorised and legitimised. As Patricia Schmuck (1987:9) has cogently argued 'the inclusion of women within the domain of inquiry must change the nature of that inquiry'. And if we examine how ethnicity and diversity contribute to the domain of inquiry and reject the location of whiteness at the centre of our theorising, the nature of that inquiry and the perspective and experiences of non-dominant groups might be re-shaped. This therefore allows for the possibility of a tolerance for ambiguity in our research work and a reexamination of 'more culturally indigenous ways of knowing research and enacting leadership' (Dillard, 2000:661). In this way, Indigenous voices are not just heard; they have the capacity to disrupt relationships and structures of inquiry and compel us to interrogate our own epistemologies and pedagogies. The intention is not to solely 'talk up' (Moreton-Robinson, 2000) or 'talk back' (hooks, 1989) but to authenticate and legitimate Indigenous voices through theorising the leadership realities of Indigenous women through situating such knowledge in the cultural spaces that they occupy.

In order to uncover the complexities and contradictions that women of colour as well as women from a range of ethnic and Indigenous groups face as educational leaders, it is imperative that a conscious attempt is made to understand the historical, social, economic and professional circumstances of 
women's lives and intersections of class, social location and ethnicity. It is feasible that such an understanding could encourage women from a range of ethnicities and social groups in a variety of geographical and political circumstances to define their own realities and contest prevailing notions of the 'universal educational leader' or the disquieting assumption of a universal sisterhood (Rigg and Trehan, 1999). What is being advocated is a sharper, more radical critique of the perpetuation of power and authority within traditional hierarchies that questions the pedagogy of leadership. Yet a cursory glance at rates of participation of women in the teaching profession and leadership roles suggests that struggles for opportunity and access remain for white women. For women from minority groups, the situation is more acute.

\section{Aotearoa/New Zealand}

In 1989 the administration of New Zealand education was reformed. Although the focus was improving the quality of teaching and learning through the decentralisation of school management based on a partnership model between the school and its community, the net effect of these reforms was the demand for schools to be fiscally efficient and publicly accountable (Codd, 1993; Thrupp, 2001). This changing legislative and administrative environment and the resultant industrial relations framework impacted variously on women's participation as leaders and managers in schools. In particular, the legislative imperative to hire individuals identified as belonging to minority groups (including women, Maori and Pasifika) has satisfied, to a limited extent, specific institutional needs. Yet 
these demands have placed an intense level of scrutiny on minorities within a minority setting (Konrad and Pfeffer, 1991). Furthermore, as Yeakey, Johnston and Adkison (1986) have argued, minority school leaders are frequently appointed in urban areas where the majority of students are of colour. This has contributed to a legalised form of urban segregation based on residential patterns and the idea that 'minority school systems are the appropriate places for minority administrators' (Yeakey, Johnston and Adkison, 1986:124). In Aotearoa/New Zealand, the majority of Maori and Pasifika students are in low decile urban schools, that is schools located in low income communities, or in rural and remote areas (Ministry of Education, 2002).

During the late 1980s and 1990s the under representation of women in education was a concern evident on the New Zealand educational landscape. Part of this concern was directed at improving the position of women across the compulsory education sector in order to provide appropriate role models for female students. Much of the rhetoric heard today would suggest that significant changes have been made. The reality is that minimal changes have occurred. The annual report of School Statistics released on 1 March 2002 indicated that 77 percent of the 45,432 teachers in New Zealand's 2,528 state schools were women (Ministry of Education, 2002). More specifically, women occupied 61 percent of the management positions (such as Deputy Principal, Curriculum Leader, Head of Department) and 38 percent of the Principal's positions (Ministry of Education, 2002). In the primary or elementary school sector, 82 percent of the 
workforce was female and in the secondary sector, 56 percent was female. These data are represented below:

“Insert Table l'

"Insert Table II"

"Insert Table III"

There are several conclusions that can be drawn from data presented in Tables I-III:

- The teaching profession is predominantly non-Maori (93 percent);

- The teaching profession is predominantly female (77 percent);

- Women remain under represented in leadership positions in New Zealand schools;

- Women dominate at all levels in special schools;

○ In primary and special schools, women are numerically dominant in management positions; and

○ It is questionable whether Equal Employment Opportunities (EEO) legislation introduced nearly twenty years ago has had an effect on the teaching profession.

There is however a discourse of silence embedded in this statistical picture. That is, considerations of class, race and ethnicity are absent from these profiles 
and thus it is arguable that a myth of the universal educational leader has been presented. While fewer women occupy principal positions and women are variably represented in management positions across the compulsory schooling sector, who these women are is difficult to determine. It has only been recently that the Ministry of Education has collected data on the ethnicity of teachers and leaders in state schools due in part to legislative requirements regarding the collection and collation of such data. However, these data are not readily available in publicly released documents. These data are presented and summarised in Table IV below.

\section{"Insert Table IV"}

This table shows the participation rate of Maori men and women at all levels in the state schooling sector. Data have not been sorted according to school sector and provide an aggregate picture. The following conclusions can be drawn:

- Numbers of Maori men and women principals are relatively similar;

- Maori women and men (as a group) are more likely to dominate in positions other than as principals or school managers;

- Maori women dominate in classrooms and in management positions;

- Maori women comprise 70 percent of Maori in the teaching profession;

- Maori remain under-represented in the teaching profession in New Zealand state schools; 
- Maori men and women in the teaching profession are dominated by 'other' ethnic groups, namely Pakeha; and

- Maori men are more likely to be principals than managers or teachers.

What is not apparent from these tables is that the 59 kura kaupapa or Maori medium (state) schools are included in these figures. Given that the staff at kura are required to have knowledge of and use te reo Maori (the Maori language) in their everyday professional work and relationships, it is likely that a high percentage of staff in these schools are Maori and that non-Maori are in the minority. What I am suggesting therefore is that Maori staff in these 59 kura inflate the overall statistical figures. What can be ascertained from these overall figures is that:

- 9.6 percent of principals are Maori;

- 6.5 percent of all management positions are held by Maori; and

○ 6.4 percent of all teachers are Maori.

Recent census data of teachers and pupils in New Zealand schools (Ministry of Education, 2002) indicate that 20 percent of the student population identify as Maori (it is likely that this rate might be higher as the list of iwi groups that are offered as a 'selection' to choose from do not always contain all iwi and many urban Maori students may not know which iwi groups they identify with). It is important to note too that 13 percent of teachers did not indicate which ethnic 
group they identified with. This may be partially explained by resistance by teachers to provide this information, or that individuals do not predominantly identify with one particular group or that the 'tick boxes' do not provide the requisite choices.

Although located in a climate of legislation that calls for equal employment opportunities for 'women and minorities', these participation rates are troubling. In order to understand this gap and to implement strategies to narrow the disparity between Pakeha women and Maori women's participation in educational leadership, we need to question embedded assumptions about leadership orthodoxies and propose a critical pedagogy that engages with discourses of distinctiveness.

\section{Maori Leadership}

Aotearoa/New Zealand occupies a unique place in the global political landscape. For the past 163 years a treaty between Maori as tangata whenua (people of the land) and tauiwi (foreigners) has existed that has created the necessary social, economic, political, constitutional and ideological pre-conditions for a metaphor of partnership between both groups (Jones, Pringle and Shepherd, 2000). Although Te Tiriti o Waitangi remains a focal point of struggle and resistance for Maori (Smith, 1997), it has the potential to redress power relations. Yet at the same time, Te Tiriti has created a dilemma of double consciousness for Maori leaders as they struggle to interpret, negotiate and survive in two distinct cultural worlds; one Pakeha (European/white) and one Indigenous. For Maori women in 
particular, trajectories of ethnicity and gender present a tension-ridden and deeply problematic dichotomy that simultaneously situates them as women and as Maori women and members of identities linked with skin colour and black consciousness (hooks, 1989). Two vital questions can be raised at this point. How is leadership exercised in Maori communities and how might we theorise the participation of Maori women as leaders?

In traditional Maori society leadership was determined according to primogeniture. Invariably senior male members led the whanau (family), hapu (sub-tribe) and ultimately iwi (tribe). Although hereditary leadership was assumed, the confirmation of a leader's position came from within the whanau that determined whether attributes such as knowledge of whakapapa (genealogy; links between the present, past and future) and tikanga (customs), wisdom and oratory skills were present. Leadership rested on the concept of mana (prestige) that was attributed to mana atua (prestige from the gods), mana whenua (prestige from the land) or mana tangata (prestige from the people) and incorporated an element of spirituality (Smith, 1992). Yet this view of leadership did not exclude women; women had complementary roles that were equally valued within Maori society. Traditionally it was the whanau (family) that provided women with their source of strength. Unlike Western women, Maori women were not considered the chattels of their husbands; they identified more strongly with their own family and property was not transferred on marriage. Although a woman might live within her husband's whanau, their role was to ensure she was protected; she always remained a part of her own whanau. This form of social 
organisation did not confine Maori women within a nuclear family structure. Because of the extended nature of the family unit, child rearing was a communal task and this enabled women to perform a wide range of roles, including leadership roles (Smith, 1992). Significantly, women played an important role in the maintenance and transmission of oral histories that ensured the survival of the history and identity of the iwi (tribe).

More specifically, Maori leadership draws on kaupapa Maori theory (Smith, 1997) that calls for whanaungatanga (relationship building) and manaakitanga (hospitality) within a framework or kaupapa that places primacy on praxis that recognises and engages hinengaro (intellectual mind), wairua (spirit) and tinana (physical body). Interconnected and interrelated are the values of kotahitanga (unity) and kaitiakitanga (guardianship of taonga or treasures). Henare (1998) conceptualised this as a koru; a symbol of an unfolding (indigenous) fern that encompasses a sense of growth, renewal and new life and that also represents the coiled ropes of the navigators who steered the original canoes to Aotearoa/New Zealand. This koru, Henare has suggested, underpins Maori philosophies, research and the practice of leadership.

"Insert Figure 1"

At the heart of the koru are five core beliefs: 
- Io: The Supreme Being or origin of all life from which came Papatuanuku (earth mother) and Ranginui (sky father); their offspring (atua) are guardians of all facets of life.

- Tapu: That which is sacred.

- Mana: Spiritual power and authority that can be applied to people, their words and acts.

- Mauri: Spiritual essence or life force.

- Hau: Spirit power and vital essence embodied in a person and transmitted to their gifts or anything they consider valuable.

Henare (1998) argues that the fundamental ethics of Maori society are derived from these core beliefs and emphasise a connection with the spiritual realm, the sacredness and vitality of all things and the significance of reciprocity on human relations. Flowing from the heart of the koru are four predominant ethics that are considered an integral aspect of tikanga (the right thing to do):

- Whanaungatanga: The ethic of belonging 
- Wairuatanga: Spirituality that connects one a person with lo, Rangi and Papa and all the atua.

- Kotahitanga: Implies solidarity and unity. And the connection with all that people do.

- Kaitiatanga: Guardianship or creation and all resources available to humans.

The koru is enveloped by two further principles:

- Te ao marama: The world of light and enlightment.

- To ao hurihuri: The changing world and recognition that the world is dynamic although traditions remain constant.

A study conducted by Ella Henry and Judith Pringle (1996) with Maori and non-Maori women-run organisations concluded that Maori women in leadership roles predominantly correlated their understanding and descriptions of their leadership practices with a Maori-centred framework. A summary of the leadership roles and associated leadership styles is presented as Table $\mathrm{V}$ below.

\footnotetext{
"Insert Table V"
} 
While it is both difficult and dangerous to locate these terms within leadership theories more broadly and feminist leadership theories more specifically, what is evident are links with family terms and relationships between Maori women leaders and their colleagues based on the values contained within Henare's koru of Maori ethics. This therefore invokes the sense of whanaungatanga and the central importance of whakapapa in providing links with a sense of identity in the $21^{\text {st }}$ century.

In more general terms, there are a number of central issues to be considered in the search for an understanding of 'Indigenous educational leadership'. In the first instance, it may not be possible to construct a unitary definition of Indigenous leadership particularly as leadership may be exercised in multiple ways in a variety of settings. Secondly, personal qualities, skills and knowledge that contribute to 'Indigenous leadership' cannot be articulated as differences between Indigenous and non-Indigenous leaders, yet relationships within Indigenous communities and relationships with non-Indigenous communities are inextricably linked (Bishop and Glynn, 1999). This therefore points to the possibility that two layers of leadership may exist within Indigenous communities: (traditional) community leadership that is derived from an Indigenous worldview that recognises skills and knowledge according to the mana (authority, respect) of an individual; and leadership as advocacy between Indigenous and non-Indigenous communities. 'Indigenous leadership often 
requires people to be able to walk confidently and with influence in two worlds' (Australian Institute of Aboriginal and Torres Strait Islander Studies, 1998:16).

\section{Implications}

A note of caution - this section offers possible suggestions as to ways in which research and theorising might be conducted that places gender and ethnicity at the centre of our work. My intention is not to provide a solution; that is neither possible nor permissible.

Knowledge production for and about educational leadership needs to be dismantled to provide a standpoint from which to theorise and research the realities of leadership through the experiences of women from a variety of ethnicities that simultaneously encourages and permits the situating of such knowledge and action in the cultural spaces in which they arose. One of the new metaphors for research that Cynthia Dillard has suggested is an 'endarkened feminist epistemology' that embodies a distinguishable cultural standpoint that is 'located in the intersection/overlap of culturally constructed socialisations of race, gender and other identities' (2000:661). And this includes acknowledging and interrogating whiteness as a specific privilege and taken-for-granted construct.

In terms of a research agenda, I am proposing that we interrogate our own thinking and research in terms of the five discourses that I have indicated in this article. The production of discourses of:

○ Privilege; 
○ Opportunity;

○ Identity;

$\circ$ Deficit; and

$\circ$ Homogeneity

have, to this point, attempted to provide explanations for the participation of women across ethnic groups in school leadership. Yet as I have pointed out, what is missing from these narratives are debates about diversity and distinctiveness between and among women that simultaneously question ways in which whiteness is constructed and positioned as the norm. What I am calling for is the production of discourses of distinctiveness that interrogate orthodox voices.

Thus, three central questions can be raised here. Firstly, 'do orthodoxies of leadership that help us to understand the exercise of leadership provide multiple understandings of the realities of leadership from a variety of perspectives'? Secondly, 'how do insights engaged in identifying with a particular race or ethnicity open up new possibilities for the research and leadership community of scholars to see phenomena and hear a multiplicity of voices in new ways'? And, finally, how can speaking about and exercising leadership become not a harmonious choir but a cacophony of voices that celebrate distinctiveness? 
This article therefore is an agitation for a tolerance of ambiguity and a space for authenticity in our research, theorising and leadership. 


\section{References}

Adler S, Laney J \& Packer M (1993) Managing Women: Feminism and Power in Educational Management, Open University Press: Buckingham.

Alston J (1999) Climbing hills and mountains: Black females making it to the Superintendency, in Brunner C (ed) Sacred Dreams: women and the Superintendency, New York: State University of New York.

Alston J (2000) Missing from action: Where are the Black female school superintendents? Urban Education, 35(5), 525-531.

Australian Institute of Aboriginal and Torres Strait Islander Studies (1998) Concept Study into an Australian Indigenous Leadership Development Program, Canberra.

Bajunid IA (1996) Preliminary explorations of Indigenous perspectives of educational management, Journal of Educational Administration, 34 (5), 50-73.

Bishop, R \& Glynn, T (1999) Culture Counts: Changing Power Relations in Education, Palmerston North: Dunmore Press. 
Blackmore, J (1999) Troubling Women: Feminism, Leadership and Educational Change, Buckingham: Open University Press.

Blackmore J \& Kenway, J (eds) (1993) Gender Matters in Educational Administration and Policy, London: Falmer Press.

Blackmore J (2002) Troubling women: The upsides and downsides of leadership and the new managerialism in Reynolds C (ed) Women and School Leadership: international perspectives, New York: State University of New York Press.

Bourdieu P (1987) What makes a social class? On the theoretical and practical existence of groups, Berkley Journal of Sociology, 32, 1-18.

Bowkett T (1996). A struggle towards a theory of professionalism for Maori women educators, Unpublished MEd thesis, Massey University.

Chase S (1995) Ambiguous Empowerment: The Work Narratives of Women School Superintendents, Amerherst: Massachusetts University Press.

Codd J (1993) Managerialism, market liberalism and the move to self-managing schools in New Zealand in Smyth J (ed) A Socially Critical View of the SelfManaging School, London: Falmer Press. 
Coleman M (2001) Achievement against the odds the female secondary headteachers in England and Wales, School Leadership and Management, Vol. 21(1), 75-100.

Collins P (1998) Fighting Words: Black Women and the Search for Justice, Minneaplois: University of Minnesota Press.

Court M (1995) Leading from behind: women in educational administration in Middleton S \& Jones A (eds) Women and Education in Aotearoa 2, Wellington: Bridget Williams Books.

Court M (1998) Women challenging managerialism: devolution dilemmas in the establishment of co-principalship in primary school in Aotearoa/New Zealand, School Leadership and Management, 18(1) 35-57.

Dillard C (1995) Leading with her life: an African American feminist (re)interpretation of leadership for an urban high school principal, Educational Administration Quarterly, Vol. 31( 4), 539-563.

Dillard C (2000) The substance of things hoped for, the evidence of things not seen: examining an endarkened feminist epistemology in educational research and leadership, Qualitative Studies in Education, 13( 6), 661-681. 
Duke DL (1998) The normative context of organizational leadership, Educational Administration Quarterly, 34(2), 165-195.

Essed P (2000) Dilemmas in leadership: colour in the Academy, Ethnic and Racial Studies, 23(5), 888-904.

Fine M (1997) Witnessing Whiteness in Fine M, Powell L, Weis L and Mun Wong, L (eds) Off White: readings on race power and society, New York: Routledge.

Fitzgerald T (2003) Changing the deafening silences of Indigenous women's voices in educational leadership, Journal of Educational Administration, 41(1), 923.

Grogan M (1996) Voices of Women Aspiring to the Superintendency, New York: State University of New York Press.

Gunew S (1994) Playing centre field: representation and cultural difference in Fuery P (ed) Representation, Discourse and Desire: contemporary Australian culture and critical theory, Melbourne: Longman Cheshire. 
Hall V (1999) Gender and educational management: duel or dialogue? in Bush $\mathrm{T}$, Bell L, Bolam R, Glatter R \& Ribbins P (eds) Educational Management: redefining theory, policy and practice, London: Paul Chapman.

Henare M (1998) Hope and Maori Self-determination, Proceedings of the 1998 Theological Symposium, Palmerston North: Pastoral Centre.

Henry E \& Pringle J (1996). 'Making voices, being heard in Aotearoa/New Zealand', Organization, Vol. 3, No. 4, pp. 534-40.

hooks b (1989) Talking Back: Thinking Feminist, Thinking Black, Boston: South End Press.

Hurty K (1995) Women principals - leading with power in Dunlap D \& Schmuck P (eds) Women Leading in Education, New York: State University of New York Press.

Jones D, Pringle J \& Shepherd D (2000) Managing diversity meets Aotearoa/New Zealand, Personnel Review, 29(3), 364-380.

Konrad A \& Pfeffer J (1991) Understanding the hiring of women and minorities in educational institutions, Sociology of Education, 64, 141-157. 
Limerick B \& Lingard B (eds) (1995) Gender and Changing Educational Management, Sydney: Hodder and Stroughton.

McGee Banks CA (2000) Gender and race as factors in educational leadership and administration in Fullan M (ed) Educational Leadership, San Francisco: Jossey-Bass, San Francisco.

Ministry of Education (2002) School Statistics (www.minedu.edu.govt).

Moreton-Robinson A (2000) Talkin' Up the White Woman: Indigenous Women and Feminism, Queensland: University of Queensland Press.

Ozga J (1993) Women in Educational Management, Buckingham: Open University Press.

Pringle J \& Timperley H (1995) Gender and educational management in New Zealand: co-option, subversion or withdrawal?' in Limerick B \& Lingard B (eds) Gender and Changing Educational Management, Sydney: Hodder and Stroughton, Sydney.

Rigg C \& Trehan K (1999) Not critical enough? Black women raise challenges for critical management learning', Gender and Education, 11(3), 265-280. 
Poplin Gosetti P \& Rusch E (1995) Re-examining educational leadership: challenging assumptions in Dunlap D \& Schmuck $\mathrm{P}$ (eds) Women Leading in Education, New York: State University of New York Press.

Schmuck P (1987) Women Educators, Albany: State University of New York.

Sergiovanni T (1992) Moral Leadership: Getting to the Heart of the Matter, San Francisco: Jossey Bass.

Shakeshaft C (1987) Women in Educational Administration, Newbury: Sage.

Skrla L (2000) The social construction of gender in the superintendency, Journal of Education Policy, 15(3), 293-316.

Slack P \& Cornelius P (1995) To walk the red road as school leaders in Dunlap D \& Schmuck P (eds) Women Leading in Education, New York: State University of New York Press.

Smith G (1997) Kaupapa Maori as transformative praxis, Unpublished PhD thesis, The University of Auckland. 
Smith L (1992) Maori women: discourse, projects and mana wahine in Middleton S \& Jones A. (eds) Women and Education in Aotearoa 2, Wellington: Bridget Williams Books, Wellington.

Strachan J (1999) Feminist educational leadership: locating the concepts in practice, Gender and Education, 11(3), 309-322.

Te Tiriti o Waitangi (1840) www.archives.govt.nz/holdings/treaty_frame.html

Thrupp M (2001) School-level education policy under New Labour and New Zealand Labour: a comparative update, British Journal of Educational Studies, 49(2), 187-212.

Tripconey P (1995) Barely scratching the surface: an Indigenous experience of education administration in Limerick B \& Lingard B (eds) Gender and Changing Educational Management, Sydney: Hodder and Stroughton.

Yeakey C Johnston G \& Adkison J (1986) In pursuit of equity: a review of research on minorities and women in educational administration, Educational Administration Quarterly, 22(3), 110-149. 


\title{
Interrogating Orthodox Voices: Gender, Ethnicity and Educational Leadership
}

\author{
Tanya Fitzgerald \\ School of Education \\ UNITEC Institute of Technology \\ Auckland, New Zealand \\ Ph: + 6498154321 ext 8776 \\ Fax: + 6498154310 \\ Email: tfitzgerald@unitec.ac.nz
}

